\title{
POLA ASUH SINGLE PARENTDALAM UPAYA MEMBINA PERILAKU SOSIAL REMAJA DI DESA JATISEENG KECAMATAN CILEDUG KABUPATEN CIREBON
}

\author{
Silvi Sintia ${ }^{1}$, Ratna Puspitasari ${ }^{2}$ \\ IAIN Syekh Nurjati Cirebon ${ }^{1,2}$ \\ syntya.amazida@gmail.com;puspitasarinana72@gmail.com
}

\begin{abstract}
Abstrak
Pengasuhan yang dilakukan oleh single parent merupakan satu fenomena di zaman kontemporer saat ini. Pola pengasuhan yang diterapkan single parent acapkali membutuhkan konsep tersendiri untuk mendidikdan mengasuh anakanaknya. Langkah ini tentu berbeda antara satu keluarga dengan keluarga yang lain. Kurangnya intensitas pengasuhan anak akibat terjadinya single parent menjadikan perhatian orang tua berkurang dan teralihkan. Dampak dari ketidakperhatian orang tua memberi peluang bagi anak untuk membentuk perilaku di luar nila-nilai yang diajarkan oleh orang tua. Latar belakang permasalah ini yaitufenomena remajayang ditinggal pergi oleh orang tuanya karena meninggal. remaja tersebut meresponnya dengan sikap dan berperilaku yang kurang wajar dan bahkan amoral, seperti membolos sekolah, merokok, dan tawuran. Adapun tujuan penelitian ini adalah untuk memperoleh data pola asuh single parent dalam upaya membina perilaku sosial remaja, bagaimana perilaku sosial remaja dan untuk mendeskripsikan faktor pendukung dan penghambat perilaku sosial remaja yang dilakukan oleh ibu single parent. Data pola pengasuhan yang diperoleh yakni, pola pengasuhan demokratis dan pola pengasuhan otoriter. Data perilaku sosial remaja terbagi menjadi dua bentuk yakni, remaja yang mampu menyesuaikan diri dan remaja yang belum mampu menyesuaikan diri. Faktor pendukung yakni, Perkembangan Ilmu Pengetahuan dan Teknologi (IPTEK) dan faktor penghambat diantaranya dari segi ekonomi, pengasuhan, dan pendidikan.
\end{abstract}

Kata kunci: pola asuh, single parent, perilaku sosial remaja

\begin{abstract}
Parenting performed by single parent is a phenomenon in contemporary times today. Parenting patterns that apply single parent often require a separate concept to educate and nurture their children. This step certainly different between one family with another family. The lack of intensity of parenting due to the occurrence of single parent makes the attention of parents are reduced and sidetracked. The impact of parent's disinterest provides an opportunity for children to form behaviors beyond the values taught by parents. The background of this problem is the phenomenon of teenagers who were left by their parents because they died. the teen responds with an attitude and behavior that is less reasonable and even immoral, such as ditching school, smoking, and brawl. The
\end{abstract}


purpose of this study is to obtain data parenting single parent in an effort to foster social behavior of adolescents, how teenagers social behavior and to describe factors supporting and inhibiting social behavior of teenagers performed by single parent mothers. Data on parenting patterns obtained are, democratic parenting patterns and authoritarian parenting patterns. Adolescent social behavior data is divided into two forms namely, adolescents who are able to adapt and adolescents who have not been able to adjust. Supporting factors, namely the Development of Science and Technology (Science and Technology) and factors inhibiting them in terms of economic, nurturing, and education.

\section{Keywords: parenting, single parent, adolescent social behavior}

\section{A. PENDAHULUAN}

\section{Latar Belakang Masalah}

Keluarga dan pendidikan adalah dua istilah yang tidak bisa dipisahkan. Sebab, dimana ada keluarga tentu ada pendidikan. Di mana ada orang tua jelas ada anak yang merupakan suatu keharusan dalam keluarga. Ketika ada orang tua yang ingin mendidik anaknya, maka pada waktu yang sama ada anak yang menghajatkan pendidikan dari orang tua. Dari sini muncul istilah "pendidikan keluarga". menurut Djamarah (2014:2) pendidikan keluarga merupakan pendidikan yang berlangsung dalam keluarga yang dilaksanakan oleh orang tua sebagai tugas dan tanggung jawabnya dalam mendidik anak dalam keluarga.

Pendidikan dasar yang baik harus diberikan kepada anggota keluarga sedini mungkin dalam upaya memerankan fungsi pendidikan dalam keluarga, yaitu menumbuhkembangkan potensi laten anak, sebagai wahana untuk mentransfer nilai-nilai dan sebagai agen perubahan kebudayaan.

Keluarga merupakan kesatuan yang terkecil di dalam masyarakat tetapi menepati kedudukan yang primer dan fundamental, oleh sebab itu keluarga mempunya peranan yang besar dan vital dalam mempengaruhi kehidupan anak, terutama pada awal maupun tahap-tahap kristisnya. Keluarga yang gagal memberi cinta kasih sayang dan perhatian akan memupuk kebencian, rasa tidak aman danindak kekerasan kepada anakanaknya. Demilian pula jika keluarga tidak dapat menciptakan suasana 
pendidikan, maka hal ini akan menyebabkan anak-anak terpelosok atau tersesat jalanya. (Skrispsi Wahyuningsih, 2008).

Pengasuhan oleh orang tua tunggal adalah salah satu fenomena di zaman kontemporer sekarang ini. Fenomena tersebut meningkat terbukti dari pendataan Badan Pusat Statistik (BPS : 2014), jumlah single parentdi Indonesiasekitar 7 juta perempuan sedangkan single parent untuk laki-laki sekitar 2 juta. Secara spesifik disalah satu wilayah Indonesia yaitu Kecamatan Ciledug juga memiliki jumlah single parentyang tinggi yakni sekitar 194 perempuan sedangkan single parent laki-laki hanya 35. Berdasarkan data tersebut dapat memberikan gambaran tingginya keluarga yang berstatus sebagai single parent perempuan.

Pola pengasuhan yang dilakukan orang tua tunggal acapkali membutuhkan strategi tersendiri dalam mengasuh dan membimbing anak. Langkah tersebut tentu akan berbeda antara satu keluarga dengan keluarga lainnya. Kurangnya intensitas pengasuhan anak akibat terjadinya orang tua tunggal menjadikan perhatian orang tua berkurang. Perhatian yang berkurang akan memberikan kesempatan bagi anak untuk membentuk perilaku di luar nilai-nilai yang diajarkan orang tuanya.

Berkaitan dengan obsevasi sementara di Desa Jatiseeng yang terjadi pada keluarga single parent disebabkan karena ditinggal suaminya akibat meninggal. oleh karena itu, untuk memenuhi kebutuhan anak-anaknya ibu single parent tersebut bekerja dengan membuka usaha di rumah ataupun bekerja sebagai karyawan swasta. Selama dalam pengasuhan, orang tua selalu menjaga dan mendidik anak-anaknya dengan baik. Namun, remaja tersebut meresponnya dengan sikap dan berperilaku yang kurang wajar dan bahkan amoral, seperti membolos sekolah, merokok, dan tawuran.

Berangkat dari sini peneliti tertarik untuk mengetahui dan perlu untuk mengkaji lebih mendalam ke dalam bentuk skripsi yang berjudul:"Pola Asuh Single Parent Dalam Upaya Membentuk Perilaku Sosial Remaja Di Desa Jatiseeng Kecamatan Ciledug Kabupaten Cirebon”. 


\section{Perumusan Masalah}

Berdasarkan latar belakang di atas, maka dapat ditarik beberapa rumusan masalah diantaranya:

a. Bagaimana pola asuh single parent dalam upaya membina perilaku sosial remaja di Desa Jatiseeng Kecamatan Ciledug Kabupaten Cirebon?

b. Bagaimana perilaku sosial remaja di Desa Jatiseeng Kecamatan Ciledug Kabupaten Cirebon?

c. Faktor apa saja yang mendukung dan menghambat upaya pembinaan perilaku sosial remaja yang dilakukan oleh ibu single parent di Desa Jatiseeng Kecamatan Ciledug Kabupaten Cirebon?

\section{Tujuan Penelitian}

Setelah menyelesaikan perumusan masalah maka tujuan penelitiannya adalah sebagai berikut:

a. Untuk memperoleh data pola asuh single parent dalam upaya membina perilaku sosial remaja di Desa Jatiseeng Kecamatan Ciledug Kabupaten Cirebon.

b. Untuk memperoleh data perilaku sosial remaja di Desa Jatiseeng Kecamatan Ciledug Kabupaten Cirebon.

c. Untuk mendeskripsikan Faktor yang mendukung dan menghambat perilaku sosial remaja yang dilakukan oleh ibu single parent di Desa Jatiseeng Kecamatan Ciledug Kabupaten Cirebon.

\section{B. KAJIAN TEORI}

\section{Pola Asuh}

Konsep mengenai pola pengasuhan ini sudah berapa kali mengalami perubahan sesuai dengan perubahan jaman, sebab dari jaman dulu keluarga berfungsi sebagai penerus budaya dari generasi ke generasi selanjutnya secara dinamis sesuai dengan situasi dan kondisi serta kebutuhan masyarakat.

Prasetyo (2003 : 1) mendefinisikan pengasuhan orang tua adalah aktivitas komplek termasuk banyak perilaku spesifik yang dikerjakan secara 
individu dan bersama- sama untuk mempengaruhi pembentukan karakter anak. Berk (2000) dalam socialization with in the family pola asuh orang tua adalah daya upaya orangtua dalam memainkan aturan secara luas di dalam meningkatkan pertumbuhan dan perkembangan anaknya. Kemudian pengasuhan berasal dari kata asuh yang berarti menjaga, merawat dan mendidik anak kecil.

\section{Tipe-tipe Pola Asuh}

Hurlock, sebagaimana dikutip oleh Chabib Thoha (1996 : 109), mengemukakan ada tiga jenis pola asuh orang tua terhadap anaknya, yakni (1) pola asuh otoriter, (2) pola asuh demokratis, dan (3) pola asuh permisif.

\section{a. Pola Asuh Otoriter}

Pola asuh otoriter adalah pola asuh yang ditandai dengan cara mengasuh anak dengan aturan-aturan yang ketat, seringkali memaksa anak untuk berperilaku seperti dirinya (orang tua), kebebasan untuk bertindak atas nama diri sendiri dibatasi. Anak jarang diajak berkomunikasi dan bertukar pikiran dengan orang tua, orang tua menganggap bahwa semua sikapnya sudah benar sehingga tidak perlu dipertimbangkan dengan anak.

Pola asuh otoriter ditandai dengan pemberian hadiah dan hukuman, hadiah dan hukuman merupakan produk dari sistem otoriter yang memperkokoh superioritas tradisional segolongan orang tua terhadap golongan lain.

b. Pola Asuh Demokratis

Pola asuh demokratis artinya orang tua memberikan kesempatan kepada setiap anaknya untuk menyatakan pendapat, keluhan, kegelisahan, dan oleh orang tuanya ditanggapi secara wajar dan bimbingan seperlunya.

\section{c. Pola Asuh Permissif}

Pola asuh ini ditandai dengan cara orang tua mendidik anak secara bebas, anak dianggap sebagai orang dewasa/muda, ia diberi kelonggaran seluas-luasnya untuk melakukan apa saja yang dikehendaki. Kontrol orang tua terhadap anak sangat lemah, juga tidak memberikan bimbingan 
yang cukup berarti bagi anaknya. Semua apa yang telah dilakukan oleh anak adalah benar dan tidak perlu teguran, arahan atau bimbingan.

\section{Single Parent}

Single parent a person who looks after their child or children without a husband wife or partner. Artinya seseorang yang menjaga anaknya tanpa suami atau istri atau rekan kerja (At Horbny,2000 : 1202).

Single parent is parent earring for a child on his/ her own. Artinya satu orang yang menjaga anaknya sendiri (Martin,1995 :382)

Sedangkan single parent families (keluarga single parent) berarti keluarga yang terdiri dari ayah ibu yang bertanggung jawab mengurus anak setelah perceraian, kematian atau kelahiran anak diluar nikah (Syamsu,2003 : 36)

\section{Perilaku Sosial Remaja}

Setiap remaja mengalami tahap-tahap perkembangan perkembangan. Tahap-tahap perkembangan remaja secara umum sama. Pada setiap perkembangan, setiap remaja dituntut dapat bertindak atau melaksanakan hal-hal (perilaku) yang menjadi tugas perkembangannya dengan baik.

Perilaku remaja menyimpang memiliki hubungan dengan penyesuaian remaja tersebut dengan lingkungannya. Hurlock (2004:39) mengatakan bahwa perilaku remaja bermasalah atau menyimpang muncul karena penyesuaian yang harus dilakukan remaja terhadap tuntutan lingkungan yang baru. Berarti semakin besar tuntuan dan perubahan semakin besar pula masalah penyesuaian yang dihadapi remaja tersebut.

Walaupun gejala perilaku bermasalah hanya tampak pada sebagian remaja, pada dasarnya setiap remaja memiliki masalah-masalah emosional dan penyesuaian sosial. Masalah itu tidak selamanya menimbulkan perilaku bermasalah atau menyimpang yang kronis. (Kartono, 2006: 44)

\section{METODOLOGI}

\section{Jenis Penelitian}

Pendekatan kualitatif adalah pendekatan yang berlandaskan pada filsafat postpositivisme, digunakan untuk meneliti pada kondisi obyek yang 
alamiah, (sebagai lawanya adalah penelitian eksperimen) dimana peneliti adalah sebagai instrumen kunci, pengambilan sampel sumber data dilakukan secara purposive dan snowbaal, teknik pengumpulan dengan trianggulasi (gabungan), analisi data bersifat induktif/kualitatif, dan hasil penelitian kualitatif lebih menekankan makna dari pada generalisasi (Sugiono, 2016: 15).

\section{Tempat dan Waktu Penelitian}

a. Tempat Penelitian

Penelitian ini berlokasi di Dusun Wage Rt/Rw: 06/04 Desa Jatiseeng Kecamatan Ciledug Kabupaten Cirebon.

b. Waktu penelitian

Waktu yang digunakan pada penelitian ini adalah 3 bulan, dimulai dari tanggal 03 April 2017 sampai dengan 30 Juni 2017.

\section{Teknik dan Instrumen Pengumpulan Data}

\section{a. Observasi}

Moleong (2010:125-126) observasi adalah teknik pengumpulan data yang dilakukan secara sistematis, yang dilakukan dengan mengadakan suatu pengamatan secara terus-menerus. Observasi dimaksudkan sebagai pengamatan dan pencatatan fenomena yang diteliti. Observasi memungkinkan melihat dan mengamati sendiri perilaku dan kejadian sebagaimana keadaan sebenarnya dilapangan.

\section{b. Wawancara}

Wawancara adalah memperoleh keterangan untuk tujuan penelitian dengan cara tanyajawab sambil bertatap muka antara pewawancara denan informan atau orang yang diwawancarai, dengan atau tanpa menggunakan pedoman (guide) wawancara, di mana pewawancara dan informan terlibat dalam kehidupan sosial yang relatif lama. Dengan demikian, kekhasan wawancara mendalam adalah keterlibatannya dalam kehidupan informan (Bungin, 2008: 108). 


\section{c. Dokumentasi}

Dokumentasi merupakan catatan peristiwa yang sudah berlalu.

Dokumentasi bisa berbentuk tulisan, gambar, atau karya-karya monumental dari seseorang. (Sugiyono, 2011 :329).

\section{HASIL PENELITIAN DAN PEMBAHASAN}

\section{Pola Asuh yang diberikan oleh ibu single parent dalam upaya membina} perilaku sosial remaja

Pola asuh yang diberikan oleh ibu single parent pada anak mempengaruhi terhadap perilaku sosial remaja. Dengan pola asuh yang diterapkan berbeda-beda pada masing-masing ibu single parent tersebut maka hasil yang didapatkan pada anak juga berbeda. Seperti penerapan kedisiplinan terhadap anak, pengambilan keputusan, pemberian penghargaan, penanaman jiwa religius pada anak, penanaman bersikap sosialisasi pada anak, hukuman bagi anak,sikap anak yang kemudian muncul dari akibat pola asuh yang diterapkan, hingga faktor yang mempengaruhi perilaku sosial remaja tersebut.

Berdasarkan temuan peneliti dalam penelitian ini bahwa pola pengasuhan oleh ibu single parent terbagi menjadi dua pola asuh. Pola asuh tersebut dinukil dari buku Kapita Seleta Pendidikan Islam 1996 yang ditulis oleh Chabib Thoha. Pola asuh tersebut pertama adalah pola asuh demokratis dan pola asuh otoriter. Hal ini terlihat pada aspek kontrol terhadap anak, pengambilan keputusan, pemberian penghargaan, peraturan, dan hukuman bagi anak.

\section{Perilaku sosial remaja di Desa Jatiseeng Kecamatan Ciledug} Kabupaten Cirebon

Setiap pola asuh yang diterapkan oleh orangtua akan memiliki hasil pada sikap anak, termasuk sikap anak terhadap lingkungan sosialnya, sikap anak terhadap orangtua dan sikap anak pada dirinya sendiri seperti cara bersosialisasi, kesadaran dalam beribadah dan pola pikir. Anak. Dalam hal ini peneliti mengambil responden (anak dari ibu single parent) sebagai gambaran perilaku sosial remaja yang ada di Desa Jatiseeng. 
Dilihat dari pola asuh yang diberikan oleh single parent dengan menerapkan pola asuh demokrasi menurut King (2013) yakni anak mempunyai tingkat keakraban yang cukup tinggi, berprestasi, bertanggung jawab secara sosial, anak mampu menyelesaikan masalah. Anak pun memiliki kebebasan berpendapat dan kebebasan untuk mengembangkan kreatifitas. Sedangkan single parent yang menerapkan pola asuh otoriter menurut Dariyo (2007) cenderung tumbuh berkembang menjadi pribadi yang membantah, memberontak dan berani melawan arus sosial.

Berdasarkan temuan peneliti dalam penelitian ini bahwa perilaku sosial remaja yang ada di desa jatiseeng terbagi menjadi dua bentuk yakni, remaja yang mampu menyesuaikan diri dan remaja yang belum mampu menyesuaikan diri. Remaja yang mampu menyesuaikan diri memiliki kemandirian yang cukup, mudah bergaul, bertanggung jawab, berprestasi namun manja. sedangkan remaja yang belummampu menyesuaikan diri memiliki sikap bergantung pada orang lain, tertutup, suka membantah, memberontak, dan melawan arus.

\section{Faktor pendukung dan penghambat upaya pembinaan perilaku sosial} remaja yang dilakukan oleh ibu single parent di Desa Jatiseeng Kecamatan Ciledug Kabupaten Cirebon

Faktor yang mendukung dalam pembinaan perilaku sosial remaja yang diasuh oleh kedua ibu single parent adalah perkembangan ilmu pengetahuan dan teknologi. Mereka mengungkapkan bahwa dengan adanya teknologi yang semakin canggih dapat memudahkan serta mudah mengakses informasi secara cepat dan instan tanpa harus mengeluarkan biaya yang banyak. Sedangkan untuk faktor penghambat, diakui ada beberapa yang merasa kesulitan diantaranya dari segi ekonomi, pengasuhan dan pendidikan.

Fenomena single parent sejak tahun 2004-an telah memiliki ketertarikan bagi subjek penelitian para akademisi dalam bidang sosiologi, Karena salah satu alasan tersebut, peneliti memilih untuk mengangkat judul mengenai pola asuh single parent dalam upaya membina perilaku sosial remaja di Desa Jatiseeng Kecamatan Ciledug Kabupaten Cirebon. 
Setelah menjalankan runtutan proses penelitian dengan menggunakan wawancara, rekaman dan foto, yang data-data tersebut diambil menggunakan teknik partisipatif, maka kini peneliti melangkahkan tulisan ke tahap selanjutnya yakni, pembahasan. Berdasarkan pemaparan yang telah digambarkan oleh peneliti dengan teks narasi diatas, maka dari itu peneliti memasuki pembahasan, sebagai berikut :

Pertama, pola pengasuhan yang dilakukan oleh ibu single parent terbagi menjadi dua pola asuh. Pola asuh tersebut dinukil dari buku Kapita Seleta Pendidikan Islam 1996 yang ditulis oleh Chabib Thoha. Pola asuh tersebut pertama adalah pola asuh demokratis. Dilihat dari arti katanya demokratis menurut astalog.com adalah kehidupan yang bersifat dan bercirikan demokrasi yang didasari prinsip-prinsip demokrasi : perdamaian, tanpa kekerasan, adanya kebebasan individu untuk menentukan nasibnya sendiri, saling menghormati.

Pernyataan di atas senada dengan ungkapan yang dilontarkan oleh Martin (1996) dalam bukunya yang berjudul 'parenting', sebagai berikut:

"Pola asuh yang memprioritaskan kepentingan anak, akan tetapi tidak ragu-ragu mengendalikan mereka. Orang tua dengan pola asuh ini bersikap rasional, selalu mendasari tindakkannya pada rasio atau pemikiranpemikiran. Orang tua tipe ini juga bersikap realistis terhadap kemampuan anak, tidak berharap berlebihan terhadap kemampuan anak. Orang tua yipe ini memberikan kebebasan kepada anak untuk memilih dan melakukan suatu tindakan dan pendekatannya kepada anak bersikap hangat".

Untuk pola asuh yang kedua, yaitu pola asuh otoriter. Menurut Ricky Selviyawati (2013) adalah sebuah sikap yang mengambil keputusan terlebih dahulu tanpa mempertimbangkan akibatnya. Sedangkan menurut KBBI berkuasa sendiri, sewenang-wenang.

Pernyataan di atas selaras dengan ungkapan yang dilontarkan Edward (2006) sebagai berikut:

"Pola asuh otoriter adalah pengasuhan yang kaku, diktator, dan memaksa anak untuk selalu mengikuti perintah orang tua tanpa banyak alasan. Dalam pola asuh ini biasa ditemukan penerapan hukuman fisik dan aturan-aturan tanpa merasa perlu menjelaskan kepada anak apa guna dan alasan di balik aturan tersebut". 
Paparan di atas dapat disimpulkan pola asuh otoriter cenderung menetapkan standar yang mutlak harus dituruti, biasanya dibarengi dengan ancaman-ancaman. Pola asuh otoriter biasanya berdampak buruk pada anak, seperti merasa tidak bahagia, ketakutan, tidak terlatih untuk berinisiatif, selalu tegang, tidak mampu menyelesaikan masalah, gemar menentang, suka melanggar norma, kepribadian lemah dan menarik diri. Anak yang hidup dalam suasana keluarga yang otoriter akan menghambat kepribadian dan kedewasaanya.

Kedua, beranjak pada analisis selanjutnya mengenai perilaku sosial remaja. Dilihat dari pola asuh yang diberikan oleh single parent dengan menerapkan pola asuh demokrasi menurut King (2013) yakni anak mempunyai tingkat keakraban yang cukup tinggi, berprestasi, bertanggung jawab secara sosial, anak mampu menyelesaikan masalah. Anak pun memiliki kebebasan berpendapat dan kebebasan untuk mengembangkan kreatifitas. Sedangkan single parent yang menerapkan pola asuh otoriter menurut Dariyo (2007) cenderung tumbuh berkembang menjadi pribadi yang membantah, memberontak dan berani melawan arus sosial.

Ketiga, yaitu faktor pendukung dan penghambat perilaku sosial, seperti yang telah dipaparkan di atas. Faktor yang mendukung dalam pembinaan perilaku sosial remaja yang diasuh oleh kedua ibu single parent adalah perkembangan ilmu pengetahuan dan teknologi. Mereka mengungkapkan bahwa dengan adanya teknologi yang semakin canggih dapat memudahkan serta mudah mengakses informasi secara cepat dan instan tanpa harus mengeluarkan biaya yang banyak. Sedangkan untuk faktor penghambat, diakui ada beberapa yang merasa kesulitan diantaranya dari segi ekonomi, pengasuhan dan pendidikan.

\section{E. KESIMPULAN DAN SARAN}

\section{Kesimpulan}

a. Pola pengasuhan yang diterapkan oleh ibu single parent di desa jatiseeng terbagi menjadi dua pola asuh yakni, pola asuh demokratis dan pola asuh otoriter. Hal ini terlihat pada aspek kontrol terhadap anak, 
pengambilan keputusan, pemberian penghargaan, peraturan dan hukuman bagi anak.

b. Perilaku sosial remaja yang ada di desa jatiseeng terbagi menjadi dua bentuk. Pertama, remaja yang mampu menyesuaikan diri dan remaja yang belum mampu menyesuaikan diri. Remaja yang mampu menyesuaikan diri memiliki kemandiran yang cukup, mudah bergaul, bertanggung jawab, berprestasi namun manja. Sedangkan remaja yang belum mampu menyesuaikan diri memiliki sikap bergantung pada orang lain, tertutup, suka membantah, memberontak dan melawan arus.

c. Faktor pendukung dan penghambat perilaku sosial remaja yang diasuh kedua ibu single parent. Pertama, Perkembangan Ilmu Pengetahuan dan Teknologi (IPTEK) dengan adanya teknologi yang semakin canggih dapat memudahkan orang tua dalam mengontrol kegiatan anak selama berada di luar rumah serta mudah mengakses informasi secara cepat tanpa harus mengeluarkan biaya banyak. Kedua, faktor penghambat diantaranya pertama, dari segi ekonomi, disebabkan karena biasanya suami yang mencari nafkah untuk keluarga namun, saat ini bergantung pada penghasilan anak. Kedua, pengasuhan, disebabkan karena tidak adanya peran membagi tugas dalam mengasuh anak. ketiga, pendidikan, disebabkan karena pendidikan orang tua yang rendah berpengaruh pada pola pikir dalam mendidik anak sehingga mempengaruhi reaksi anak terhadap lingkungan.

\section{Saran}

Berdasarkan kesimpulan dan temuan pada penelitian yang telah dilakukan. Maka peneliti dapat memberi saran sebagai berikut:

a. Anak

Anak hendaknya bangga dengan keadaan ibunya sebagai single parent yang dapat mengurus rumah tangga serta mengasuh anak-anak seorang diri. 
b. Orang tua

Ibu sebagai seorang single parent hendaknya selalu berpikir positif dan senantiasatetap bersemangat dalam mencari nafkah untuk memenuhi kebutuhan keluarga.

c. Masyarakat

1) Tokoh Agama

Tokoh Agama hendaknya memberikan perhatian dan nasihat kepada remaja agar bisa berpikir positif terhadap kehidupan keluarganya yang tidak utuh dan harus bisa bersikap lebih dewasa dan diharapkan bisa menunjukan kepada masyarakat bahwa memiliki kepribadian yang tegas, memiliki pemahaman agama yang baik agar tidak mudah di pengaruhi oleh orang lain.

2) Tokoh Masyarakat

Masyarakat hendaknya tidak memandang sebelah mata ibu yang menjadisingle parent dengan menghargai dan menghormati hak dan kewajibannya sebagai bagian dari masyarakat sehingga kehidupan bermasyarakat tetapdapat berjalan harmonis dan dinamis.

3) Aparatur Pemerintah

Pemerintah hendaknya memberikan perhatian dengan mengadakanpelatihan keterampilan dan memudahkan akses dalam peminjaman modal bagi ibu sebagai single parent dalam rangka meningkatkan taraf hidup serta mengadakan sosialisasi mengenai peran penting single parent dalam mengasuh anak.

\section{DAFTAR PUSTAKA}

Badan Pusat Statistik (BPS), BKKBN, Departemen Kesehatan dan Macro Internasional. Survei Kesehatan Reproduksi Remaja tahun 2014. Journal. Jakarta.

Berk, Laura. 2000. Child Devoplement. USA : Allyn and Bacon.

Chabib, Thoha. 1996. Kapita Selekta Pendidikan Islam. Yogyakarta : Pustaka Pelajar. 
Dariyo, A. 2007. Psikologi Perkembangan Anak Tiga Tahun Pertama (Psikologi Atitama). Bandung : Refika Aditama.

Djamarah, Syaiful Bahri. 2014. Pola Asuh Orang Tua dan Komunikasi dalam Keluarga Upaya Membangun Citra Membentuk Pribadi Anak. : Jakarta : Rineka Cipta.

Hornby. A.S. 2000. Oxford Advance leaner's Dictionary. Oxford : Oxford University Press.

Hurlock, Elizabeth B. 2004. Psikologi Perkembangan Suatu Pendekatan Sepanjang Rentang Kehidupan. Jakarta : Penerbit Erlangga.

Kartono, K. 2006. Patologi sosial 2 kenakalan remaja. Jakarta: Raja Grafindo Persada.

King, L. A 2013. Psikologi umum: Sebuah Pandangan Apresiatif. Jakarta: Salemba Humanika (Karya Asli Diterbitkan pada 2010).

Martin, Maccoby. 1996. Parenting. Alih Bahasa: Veronika. Surabaya: Obor.

Moleong, Lexy J. 2010. Metode Penelitian Kualitatif. Bandung : Remaja Rosda Karya.

Prasetyo, G Tembong. 2003. Pola Pengasuhan Anak. Jakarta : Aksara Baru

Ricky Selviyawati 2013.https://www.kompasiana.com/selviii/sikap-otoriter-tidakbaik-untuk-organisasi.html

Sugiyono. 2011. Metode Penelitian Kuantitatif, Kualitatif, dan R\&D. Bandung : Alfabeta.

Yusuf, Syamsu. 2009. Psikologi Perkembangan Anak dan Remaja. Bandung : Remaja Rosdakarya. 